\title{
PREVENTION OF TERRORIST CRIMES: TRENDS AND \\ RECOMMENDATIONS
}

\author{
Konstantin Popov, \\ PhD, Associate Professor, \\ Russian University of Transport, Moscow, Russia \\ Anil Sarwal, \\ PhD, Professor, \\ Chandigarh University, India
}

\begin{abstract}
The authors of the article analyze the features of countering international terrorism in the context of complex trends in the spread of extremist ideas and the deformation of the role of Islam in the lives of ordinary Muslims. The study is of a practical nature and is aimed at offering practical recommendations for the prevention of terrorism. Special attention is paid to possible measures to combat this phenomenon in the North Caucasus region.
\end{abstract}

Key words: terrorism, terrorist crimes, anti-terrorism, prevention of terrorist crimes.

JEL codes: F-52, K-14.

\section{Introduction}

There are a large number of international legal documents aimed at combating international terrorism. However, the adoption of various conventions by States does not always lead to their automatic implementation and use in practice. There is a problem of the notorious 'double standards' when different States interpret the phenomenon of international terrorism in different ways. We believe that this contradiction arises due to the absence of a comprehensive, unified international treaty (normative legal document) on international terrorism and the 
fight against it, which would generalize the existing experience of combating terrorism, standardize and codify a single concept of international terrorism and a set of measures and methods of combating it, and also establish uniform measures and conditions for the emergence and bringing to legal responsibility of individuals, organizations, states and other actors in international relations when they commit (or support) terrorist acts (see Fig.1) of an international nature.

\section{Main part}

In our opinion, the necessary methods of combating international terrorism could be:

\section{a) Preventive measures:}

- Preventing the use of the territories of states as an arena for planning, organizing, preparing and carrying out terrorist crimes, initiating or participating in these crimes in any form, including preventing the penetration of terrorist elements, or obtaining asylum or the right to stay in their territories, individually or collectively, or their acceptance, training, arming, financing, or providing them with any means of service;

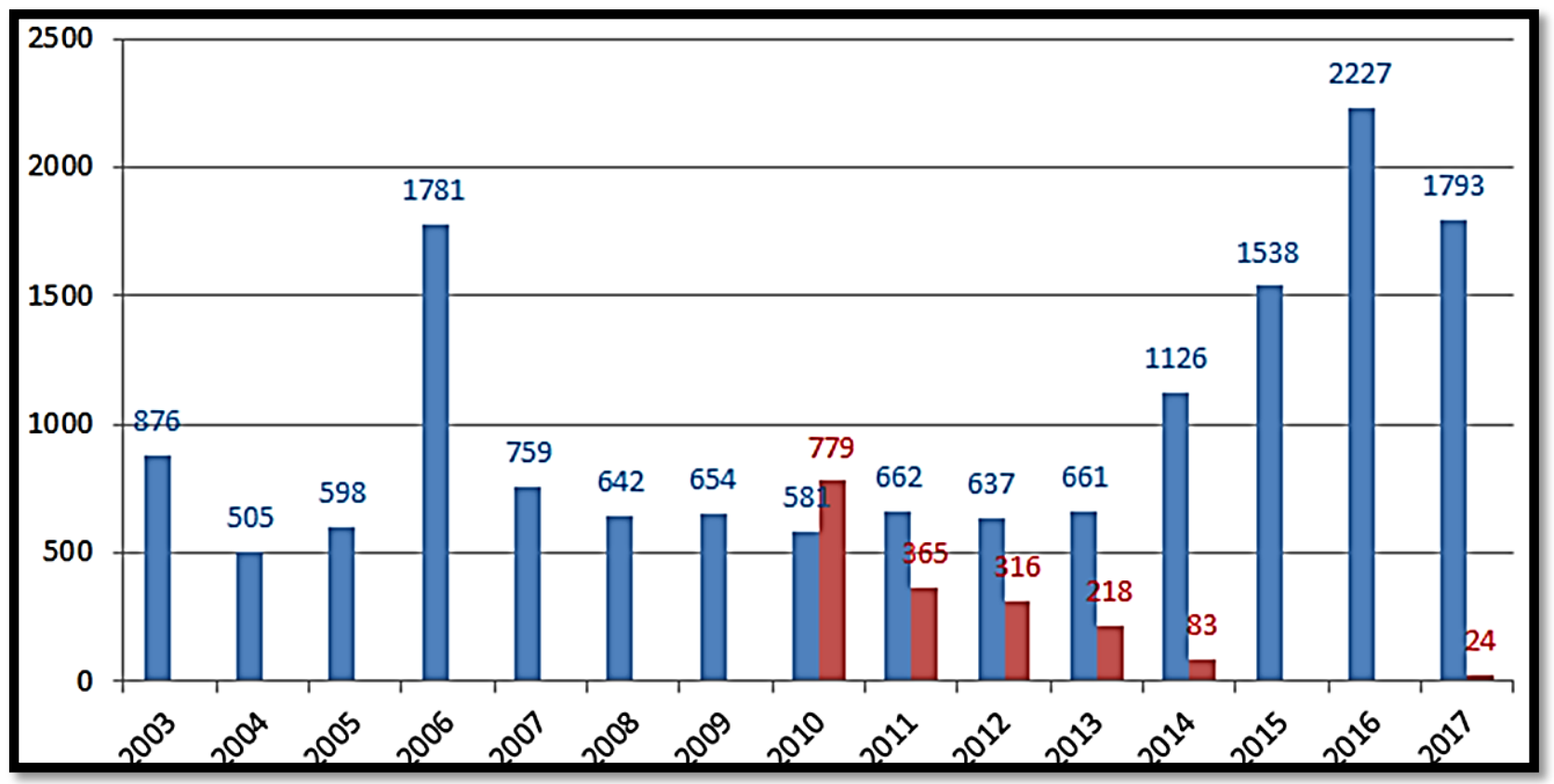

Fig.1.Terrorist crimes in Russia in the period of 2003-2017 (blue column is for the terrorist crimes, red one is for the crimes of terrorism character) 
- Cooperation and coordination between countries affected by similar or common terrorist crimes;

- Development and strengthening of systems related to the detection of the transportation, export, accumulation and use of weapons, ammunition and explosives, as well as other means of aggression, murder and destruction, in addition to strengthening cross-border and customs control in order to prevent their transfer from one country to another, if they are not intended for specific legitimate purposes;

- Development and strengthening of systems related to surveillance procedures, border security, as well as sea and air border crossing points in order to prevent penetration through them;

- Strengthening the protection and security of well-known statesmen, vital structures, public transport facilities, diplomatic and consular officials and missions, as well as regional and international organizations accredited in a particular State, in accordance with the conventions and rules of international law governing these issues;

- Facilitating security intelligence activities;

- Creation of a unified International database on terrorism, which will serve as a tool for collecting and analyzing information on terrorist elements, groups, movements and organizations around the world.

\section{b) Counteraction measures:}

- Arrest of persons who have committed terrorist crimes and their prosecution in accordance with the provisions of international instruments on combating terrorism;

- Seizure of property and/or funds used or related to a terrorist crime;

- The elimination of terrorist training bases and camps, if intelligence data and other competent authorities have shown that the previously mentioned facilities are such; 
- Disbandment of illegal armed groups, detachments stationed on the territory of any state.

- Strengthening the protection systems of important strategic objects located on the territory of the state. This includes the protection of nuclear and nuclear facilities (reactors, storage facilities, etc.); warehouses, storage facilities and arsenals of weapons; military-industrial complex enterprises; various biological, chemical and other research centers, factories.

- Establishment of effective cooperation between the competent authorities of states and citizens in the fight against terrorism, including the provision of adequate guarantees and rewards to encourage the reporting of terrorist acts and the provision of information to help their disclosure, as well as cooperation in the arrest of criminals;

- Ensuring effective protection of information stored in a database on terrorism in any state;

- Ensuring effective protection of persons working in the field of criminal justice, as well as witnesses and investigators;

- Providing necessary assistance to victims of terrorism;

- Ensuring the extradition and disclosure of persons associated with or financing terrorists;

- Elimination of communication channels between various terrorist organizations and criminal groups operating on the territory of any of the states.

In order to ensure information security and combat international terrorism, it is necessary:

a) close and block all websites and Internet resources operating within the domains of certain countries that contain material of a terrorist nature and produce propaganda of extremist ideas, conduct propaganda in favor of supporting the activities of terrorists and raising funds for their needs;

b) eliminate all printed publications with extremist content; 
c) eliminate or prohibit the broadcast of television speeches, Internet addresses of terrorist leaders; close Internet portals through which terrorists carry out propaganda of their ideas;

d) block the radio speeches of terrorist leaders to the public;

e) to ensure comprehensive propaganda in any mass media directed against terrorist movements and extremism;

f) ensure that regular speeches and appeals by leading authoritative politicians, cultural and religious figures aimed at spreading the ideas of combating terrorism, explaining to citizens the true goals of terrorists and thus creating in their minds a real image of an enemy terrorist.

\section{Conclusion}

Since the development of extremism and terrorism in the North Caucasus is directly related to the process of politicization of Islam, it is wiser first of all to 'mitigate' the influence of this process in the North Caucasus region, and then try to eliminate various extremist manifestations.

The main ways to reduce the degree of politicization of Islam and prevent the spread of jihadism and radicalism in the North Caucasus could be the following measures:

1) the combination of the ideas of 'open Islam' with education and reliance on the family category;

2) the practice of deterministic consensus;

3) differentiation of the concepts of 'psychology of faith' and 'psychology of war';

4) support of the transformist course in order to provide mechanisms for the equal participation of the Islamic world in international affairs, assistance in unlocking the potential of the Islamic world and contributing to the further development of humanity in order to help it overcome internal destructive phenomena, since Islamic radicalism can have legitimate forms of manifestation; 
5) identification in the general flow of Islamic political ideas and theories of those forces that can balance the rather noticeable growth of authoritarian and radical concepts and make up the "pole of moderation";

6) rejection of 'double standards' in politics towards the Islamic world and from creating an 'enemy image' of Muslims,

7) refusal to 'export democracy' to the Islamic world from the outside;

9) support the process of formation of mechanisms for the political evolution of Islamic political movements of a transformist orientation, expressing the interests and cultural identity of the most diverse strata of Muslim society, into open civil institutions that would operate, including on the world stage.

Speaking about the practice of deterministic consensus, we mean the following:

1) conflicts arising from the politicization of Islam and the spread of Islamism should be settled not by violent methods, but on the basis of negotiation processes and recognition of the principle of mutual responsibility of the conflicting parties;

2) these negotiations should include a number of "determinants" common to all religions. I consider the family category to be such a 'permanent' one. The family is the basis for the education of values and life attitudes of the individual. For Muslims, this category is of great importance. In order for a young Muslim not to fall under the influence of various extremist organizations, it is necessary to ensure a stable standard of living for his family, provide this person with a high level of education and enlightenment, expand the circle of employment for him;

3 ) contradictions related to the politicization of Islam and the transformation of this faith into a political weapon should be regulated on the basis of international law and the norms of Islamic Sharia.

4) Finally, for a true Muslim, the 'psychology of faith' is the greatest value and a tribute to the centuries-old history of the development of Islam, it is a sense of justice and solidarity towards other religions. And the 'psychology of war' is a crime against humanity, an illegal action and a violation of universal values. 
We propose the following main methods for combating and preventing extremism in the North Caucasus region:

- it is necessary to open branches of the Department for Countering Extremism under the Ministry of Internal Affairs of the Russian Federation in all seven subjects of the North Caucasus Federal District, to unite the anti-terrorist commissions of the subjects of the Russian Federation with these branches, to include in this structure one highly qualified specialist from the spiritual administration of Muslims in the regions of the North Caucasus Federal District; this measure is necessary to make the existing system of countering terrorism in Russia more compact and as effective as possible;

- to improve the methodology of conducting special operations, to ensure the coordinated interaction of law enforcement agencies and law enforcement agencies, it is necessary to carefully plan and scientifically substantiate these operations; each special unit should have at least one military specialist with knowledge of local dialects, peculiarities of clan contradictions of local settlements;

- it is necessary to develop special 'memos' for persons participating in special operations, in which national customs and traditions, psychology, the essence of interethnic and other relations in the area of the operation are revealed in a popular form, which minimizes possible conflicts between the participants of the operation with the local population;

- it is necessary to control the departure of Caucasian youth to foreign Islamic educational institutions; applications for the desire to study at a foreign Muslim educational institution must be submitted to the branches of the Department for Countering Extremism. 


\section{References}

1. Katzman K. Terrorism: Middle Eastern Groups and State Sponsors. - L., 2002.

2. Keohane R.O., Nye J.S. Power and interdependence. - N.Y., 2000.

3. Kepel Gilles. Les Banlieues de l'Islam: Naissance d'une religion en France. Paris : Editions du Seuil, 2004.

4. Markell Patchen. Bound by recognition. - Princeton: Princeton University Press, 2003.

5. Muslim Extremism in Egypt: The Prophet and Pharaoh by Gilles Kepel, Jon Rothschild, L., 2002.

6. Non-Military Security and Global Order: The Impact of Extremism, Violence and Chaos on National and International Security by Peter Chalk, 2000.

7. Naked Guide to Life and Death: Experts, Extremism, Evolution, Education by David Jon Peckinpaugh, 2002. 